\title{
Chemoprevention of esophageal adenocarcinoma
}

\author{
Julian A. Abrams
}

\begin{abstract}
The incidence of esophageal adenocarcinoma (EAC) is rising rapidly in Western countries, and effective chemoprevention for this malignancy is lacking. Endoscopic surveillance of patients with Barrett's esophagus is currently employed to diagnose EAC at earlier stages, but this strategy has several limitations. Non-steroidal anti-inflammatory drugs and proton pump inhibitors are the most promising agents for prevention of EAC, and a randomized controlled trial of aspirin and esomeprazole is ongoing. Other agents under investigation include green tea, berries, and antioxidants. Cost-effectiveness analyses have shown that chemopreventive agents need to be highly effective at preventing EAC in order to have benefit beyond endoscopic surveillance.
\end{abstract}

Keywords: esophageal cancer, adenocarcinoma, chemoprevention

In Western countries, the incidence of esophageal adenocarcinoma (EAC) has risen at a rapid rate over the past 30 years [Kubo and Corley, 2002; Vizcaino et al. 2002]. The reasons for this alarming trend are not entirely understood, but the increasing prevalence of obesity and associated acid reflux likely play a significant role [Lagergren et al. 1999a,b]. Unfortunately, the overall survival of EAC remains low ( $15 \%)$, and only $24 \%$ of esophageal cancer cases in the United States are diagnosed while still localized [Jemal et al. 2007].

Barrett's esophagus (BE) has long been recognized as the primary precursor lesion to EAC [Spechler, 2002]. In patients diagnosed with $\mathrm{BE}$, periodic endoscopic surveillance is performed for the detection of high-grade dysplasia or early carcinoma. While this strategy results in diagnosis of adenocarcinoma at earlier stages (and possibly improved overall survival) [Corley et al. 2002; van Sandick et al. 1998; Wright et al. 1996], the overwhelming majority of new cases of adenocarcinoma never receive a prior diagnosis of BE [Schlansky et al. 2006].

There are several problems with relying solely on endoscopic surveillance for the prevention and early identification of EAC. Most BE patients are initially diagnosed after an upper endoscopy performed for symptoms of acid reflux. The prevalence of frequent gastro-esophageal reflux disease (GERD) symptoms in the United States is estimated at 20-25\% [El-Serag et al. 2004b], but only a small proportion of these patients will have BE [Shaheen and Ransohoff, 2002]. Additionally, a high proportion of BE patients deny a history of reflux symptoms [Ronkainen et al. 2005; Rex et al. 2003]. Once BE is diagnosed, the incidence of progression to adenocarcinoma is low, estimated at $\sim 0.5 \%$ per year [Shaheen and Ransohoff, 2002]; and therefore the number of surveillance endoscopies that need to be performed to significantly impact the overall survival in EAC is large.

As such, EAC is an attractive target for the development of an effective chemopreventive agent. In this paper, the published literature will be reviewed on the chemoprevention of EAC (Table 1).

\section{Nonsteroidal anti-inflammatory drugs}

Epidemiologic studies have consistently demonstrated a protective effect of nonsteroidal antiinflammatory drug (NSAID) use on risk of EAC [Duan et al. 2008; Anderson et al. 2006; Vaughan et al. 2005; Bardou et al. 2004; Gammon et al. 2004; Corley et al. 2003; Farrow et al. 1998; Funkhouser and Sharp, 1995]. A cohort study using data from the National Health and Nutrition Examination Survey (NHANES) reported a $90 \%$ reduction in the risk of death from esophageal cancer (all cell types) among
Therapeutic Advances in Gastroenterology

(2008) 1(1) 7-18

DOI: $10.1177 /$

$1756283 \times 08093568$

C) SAGE Publications 2008 Los Angeles, London, New Delhi and Singapore

Correspondence to: Julian A. Abrams, MD, MS Division of Digestive and Liver Diseases, Columbia University Medical Center New York, NY, USA ja660Rcolumbia.edu 
Table 1. Chemopreventive interventions under investigation for esophageal adenocarcinoma and current levels of evidence.* $^{*}$

\begin{tabular}{|c|c|}
\hline & Level of evidence \\
\hline $\begin{array}{l}\text { NSAIDs }^{\dagger} \\
\text { Proton pump inhibitors } \\
\text { Green tea (Poly E) }^{\dagger} \\
\text { Folic acid } \\
\text { Black raspberries } \\
\text { Diet high in fruits and vegetables } \\
\text { Antioxidants } \\
\text { Superoxide dismutase } \\
\text { Thioproline }\end{array}$ & $\begin{array}{l}1 \\
1-2 \\
2 \\
2 \\
3 \\
2 \\
2\end{array}$ \\
\hline Retinoic acid (vitamin A) & $2-3$ \\
\hline \multicolumn{2}{|c|}{$\begin{array}{l}\text { NSAIDs, nonsteroidal anti-inflammatory drugs. } \\
\text { *Level 1: High-quality cohort studies; consistent findings } \\
\text { across studies; Level 2: Lower-quality cohort or case-control } \\
\text { studies; meta-analyses of lower-quality studies; inconsistent } \\
\text { findings across studies; Level 3: Extrapolations from bench } \\
\text { research. } \\
\text { 'Currently being studied in randomized controlled trials. }\end{array}$} \\
\hline
\end{tabular}

aspirin users [Funkhouser and Sharp, 1995]. In Northern Ireland, regular NSAID use was associated with a reduced odds of both $\mathrm{BE}$ (OR 0.40; 95\% CI 0.19-0.81) and EAC (OR 0.58; 95\% CI 0.31-1.08) [Anderson et al. 2006]. The authors hypothesized that there may have been a confounding by indication, and that NSAIDs were possibly avoided in patients with GERD due to symptom exacerbation. In a secondary analysis, however, a higher proportion of patients with GERD symptoms than without were NSAID users.

In a separate prospective cohort study of patients with BE, current NSAID use was associated with a reduced risk of progression to EAC (HR 0.32 ; 95\% CI 0.14-0.76) [Vaughan et al. 2005]. A meta-analysis of aspirin, NSAID use, and esophageal cancer reported a significantly reduced odds of EAC in aspirin and NSAID users (OR 0.67; 95\% CI 0.51-0.87) [Corley et al. 2003].

The underlying mechanisms behind this protective effect are not entirely clear. One possible explanation is the inhibition of cyclooxygenase2 (COX-2). Cyclooxygenase- 1 (COX-1) is constitutively expressed in the gastrointestinal tract. COX-2 expression is generally not observed in normal gastrointestinal mucosa, but has been described in multiple epithelial malignancies [Howe and Dannenberg, 2002], although its expression is often heterogeneous [Abdalla $e t$ al. 2005]. The exact role that COX-2 plays in neoplastic progression to EAC has not been well elucidated. COX-2 is expressed at progressively increased levels from $\mathrm{BE}$ to dysplasia to adenocarcinoma [Mehta et al. 2006; Morris et al. 2001; Shirvani et al. 2000; Wilson et al. 1998]. Bile acid exposure in the esophagus results in increased COX-2 expression in $\mathrm{BE}$ as well [Zhang et al. 2001]. Inhibition of COX-2 in vitro and in vivo decreases expression of markers of cellular proliferation and induces apoptosis in both $\mathrm{BE}$ and EAC [Kaur et al. 2002; Buttar et al. 2002a; Souza et al. 2000], and results in decreased development of EAC in a rat model [Buttar et al. 2002b].

While randomized controlled trials using both COX-nonselective (aspirin) and COX-2 selective (celecoxib) inhibitors have demonstrated a reduced risk of the development of colorectal adenomas (RR 0.55-0.81) [Arber et al. 2006; Bertagnolli et al. 2006; Baron et al. 2003; Sandler et al. 2003], treatment with COX-2 selective inhibitors has not proved successful to date as a chemopreventive agent for EAC. The Chemoprevention for BE Trial (CBET) Study Group recently reported the results of a randomized controlled trial of celecoxib for the prevention of progression in patients with $\mathrm{BE}$ with low- or high-grade dysplasia [Heath et al. 2007]. No significant differences were seen between the celecoxib and placebo groups with respect to the proportion of patients who progressed or with respect to markers of progression, including COX-2 expression. The negative results of this study may have been partly due to various factors: there was a high rate of histologic regression in both subjects with baseline lowgrade dysplasia $(50 \%)$ and high-grade dysplasia $(25 \%)$. Additionally, the histological endpoints of the study are difficult to interpret in light of both high-sampling error in endoscopic surveillance for $\mathrm{BE}$ as well as poor inter- and intra-observer variability among pathologists, particularly for the diagnosis of low-grade dysplasia.

Given the consistent protective effects of NSAID use for EAC in epidemiologic studies, there may be alternative mechanisms independent of cyclooxygenase that underlie the antineoplastic properties of NSAIDs. In one population-based case-control study, NSAID use was associated with a reduced odds of EAC only for tumors expressing cyclin D1, which is involved in cellular proliferation (OR $0.45 ; 95 \%$ CI $0.26-0.79$ ) [Gammon et al. 2004].

There have been no randomized controlled trials using nonselective NSAIDs for the prevention 
of EAC. The Aspirin for the Prevention of Esophageal Cancer Trial (AsPECT) is an ongoing large, multicenter randomized controlled trial that is evaluating the effects of aspirin $300 \mathrm{mg}$ daily (vs no aspirin) on all-cause mortality and on the rate of progression to high-grade dysplasia or adenocarcinoma in patients with BE [ Jankowski and Moayyedi, 2004]. The results of this study are eagerly anticipated.

\section{Proton pump inhibitors}

EAC is associated with a history of acid reflux symptoms [Lagergren et al. 1999a; Chow et al. 1995], and acid reflux likely plays an important role in the development of BE [Shaheen and Ransohoff, 2002]. However, it is not clear if gastroesophageal reflux contributes to the neoplastic progression of BE to EAC. Patients with BE have increased acid exposure compared to non-BE heartburn patients, and proton pump inhibitors (PPIs) are effective at reducing intragastric $\mathrm{pH}$ and subsequent esophageal exposure to acidic reflux [Katz et al. 2007, 2006; Fiorucci et al. 1989; Gillen et al. 1987]. The use of PPIs has increased dramatically since their development more than 20 years ago, but the incidence of EAC has continued to rise at an alarming rate despite the widespread use of this class of medications.

The epidemiologic data do not convincingly support the use of PPIs for the prevention of neoplastic progression in patients with $\mathrm{BE}$. Long-term PPI use in BE does not result in a significant change in the length of BE [Cooper et al. 2006]. Epidemiologic studies suggest that PPI use in patients with BE may be associated with lower rates of neoplastic progression [Hillman et al. 2008; Hillman et al. 2004]. In a study by El-Serag et al. [2004a] of veterans with $\mathrm{BE}, \mathrm{PPI}$ use (compared to histamine $\mathrm{H}_{2}$ antagonists and no acid suppression) had a lower risk of progression to dysplasia (HR 0.25; 95\% CI 0.13-0.47). However, a case-control study from the UK demonstrated an increased risk of EAC in patients who received acid suppressive therapy ( $\mathrm{H}_{2}$ antagonists or PPIs) for GERD symptoms or $\mathrm{BE}$ (OR 5.42; 95\% CI 3.13-9.39) [Garcia Rodriguez et al. 2006], and a separate populationbased case-control study from the United States failed to show an association between acid suppression with $\mathrm{H}_{2}$ antagonists and risk of EAC [Farrow et al. 2000]. Many of these studies have been limited by confounding by indication, inadequate assessment of adequacy of surveillance intervals and biopsy sampling, and reasons for not taking PPIs in the comparison groups.

Acid exposure in BE-associated EAC cell lines has been shown to activate the proliferative and anti-apoptotic MAPK pathway and increase COX-2 expression [Souza et al. 2004, 2002]. However, more recent in vitro studies suggest that acid exposure has antiproliferative effects in nondysplastic BE [Feagins et al. 2007; Zhang et al. 2007]. These seemingly discrepant findings may be due to differential responses to acid exposure in nondysplastic vs cancer cell lines. Additionally, early ex vivo studies using endoscopic biopsy specimens suggested that pulsed acid exposure (as compared to continuous acid exposure) resulted in increased cellular proliferation [Fitzgerald et al. 1996], although interpretation of these results is complicated by the presence of multiple cell types (including stroma and immune cells) in biopsy specimens.

Acid exposure does not result in genetic changes normally associated with enhanced cellular proliferation in BE cell lines, while results have been mixed in studies of BE-associated adenocarcinoma cell lines [Hao et al. 2007; Morgan et al. 2004]. An in vivo study of BE tissue demonstrated reduced cellular proliferation after six months of effective acid suppression with lansoprazole [Ouatu-Lascar et al. 1999]. A separate study of patients with $\mathrm{BE}$ who received PPI therapy demonstrated reduced p16 and increased cyclin D1 expression as compared to $\mathrm{BE}$ patients not receiving acid suppressive therapy [Umansky et al. 2001]. Effective acid suppression (as demonstrated by $\mathrm{pH}$ monitoring) in $\mathrm{BE}$ patients resulted in reduced cellular proliferation but had no effect on apoptosis or COX-2 expression [Lao-Sirieix et al. 2006].

There are hypothetical concerns that PPIs could promote neoplastic progression in BE. PPI therapy often results in secondary hypergastrinemia [Koop et al. 1990]. Both experimental and epidemiologic data support a role for gastrin in the development of colorectal neoplasia [Georgopoulos et al. 2006; Thorburn et al. 1998; Sobhani et al. 1993; Smith and Solomon, 1988; Kusyk et al. 1986]. In BE cells, gastrin binds to the CCK-2 receptor, which enhances proliferation and has antiapoptotic effects [Harris et al. 2004; Haigh et al. 2003]. 
Elevated tissue gastrin expression was associated with increased cellular proliferation and COX-2 expression in a series of patients with $\mathrm{BE}$ [Abdalla et al. 2004].

Given the apparent conflicting effects of acid suppression on markers of neoplasia in the laboratory and inconclusive epidemiologic data, it is not possible to support the use of PPIs solely for the prevention of EAC. Hopefully, the AsPECT trial described above will help address the role of PPIs in the prevention of adenocarcinoma in patients with BE. Patients will be assigned to esomeprazole either $80 \mathrm{mg}$ daily or $20 \mathrm{mg}$ daily (which can be increased based on symptoms) [Jankowski and Moayyedi, 2004]. While the trial does not have a placebo arm, the $2 \times 2$ design will allow for the assessment of differences in effect of high-dose vs low-dose PPI therapy on neoplastic progression in BE.

\section{Green tea}

Epidemiologic studies from Asia suggest that high consumption of green tea is associated with a reduced risk of various epithelial malignancies [Cabrera et al. 2006]. In a cohort of nearly 70,000 women in China, regular green tea consumption was associated with a significantly decreased risk of colorectal cancer (RR 0.63; 95\% CI 0.45-0.88) [Yang et al. 2007]. A meta-analysis also demonstrated an inverse relationship between green tea consumption and colorectal cancer (OR 0.82; 95\% CI 0.69-0.98) [Sun et al. 2006]. The association between green tea consumption and risk of EAC has not been directly studied, in part due to the low incidence of EAC in Asia.

Several antineoplastic properties have been identified among green tea metabolites, which include epigallocatechin-3-gallate (EGCG) and other catechins. EGCG inhibits cell growth, induces apoptosis, and reduces COX-2 expression [Masuda et al. 2003, 2001]. EGCG also has antioxidant properties and may have antiinflammatory properties as well [Saffari and Sadrzadeh, 2004; D’Alessandro et al. 2003].

There is currently an ongoing placebo-controlled phase IB trial of polyphenon E (Poly E), a compound containing EGCG (data unpublished). Patients with BE and no dysplasia or low-grade dysplasia will receive either Poly E or placebo for six months. The primary aim of the study is to demonstrate safety and determine the maximum tolerated dose. Secondary aims of the study include evaluation of the effects of Poly $\mathrm{E}$ on expression of various neoplastic biomarkers, including cyclin D1, COX-2, and Ki-67.

\section{Folic acid}

Folic acid is a water soluble vitamin B present in many foods. Folate plays an important role in DNA synthesis and methylation, and deficiency of this vitamin can result in DNA damage and abnormal DNA methylation [Choi and Mason, 2000]. Population-based case-control studies have showed that the highest levels of folate intake are associated with a significantly reduced odds of EAC [Chen et al. 2002; Mayne et al. 2001], and results of a recent meta-analysis demonstrated that high folate intake is associated with a reduced risk of EAC (RR 0.50; 95\% 0.39-0.65) [Larsson et al. 2006]. Additionally, there are functional polymorphisms of methyl tetrahydrofolate reductase (MTHFR) that play important roles in folate metabolism, and the relationship between folic acid intake and cancer risk may vary between individuals with differing polymorphisms [Larsson et al. 2006].

While epidemiologic data also strongly suggest an association between high folate intake and reduced risk of colorectal cancer [Larsson et al. 2005; Baron et al. 1998; Giovannucci et al. 1998, 1995], a recent randomized placebo-controlled trial demonstrated no benefit of folate on the risk of recurrent adenomas [Cole et al. 2007]. Therefore, until a randomized controlled trial is performed in esophageal cancer, folic acid cannot be recommended for the prevention of EAC.

\section{Berries}

Freeze-dried berries, particularly blackberries, raspberries, strawberries, and cranberries, have gained interest as a chemopreventive agent. Like green tea, berries contain high concentrations of polyphenols. Additionally, they contain folic acid and antioxidants such as beta carotene and vitamins C and E [Stoner et al. 2007]. Diet supplementation with freeze-dried black raspberries results in decreased COX-2 expression in the rat esophagus [Chen et al. 2006]. In an openlabeled study, ten patients with nondysplastic $\mathrm{BE}$ took daily freeze-dried black raspberries for six months. After a six-month period, there was 
a reduction in various urinary markers of oxidative stress [Kresty et al. 2006]. The results of tissue analysis from the total study population (target 20) have not yet been reported.

\section{Diet}

Various epidemiological studies have examined the associations between dietary patterns and risk of EAC. Two separate population-based case-control studies demonstrated a significantly reduced odds of EAC among individuals with the highest amounts of fruit and vegetable intake [Terry et al. 2001; Cheng et al. 2000]. However, a large cohort study of over 500,000 patients from Europe (the European Prospective Investigation into Cancer and Nutrition (EPICEURGAST)) found no significant association between fruit (HR $0.84 ; 95 \%$ CI $0.60-1.17$ ) or vegetable (HR $0.72 ; 95 \%$ CI $0.32-1.64$ ) intake and risk of EAC [Gonzalez et al. 2006]. A separate cohort study of over 490,000 patients who took part in the NIH-AARP Diet and Health Study reported no association between fruit and vegetable intake and risk of EAC (OR 0.98; 95\% CI 0.90-1.08) [Freedman et al. 2007].

Studies of fiber consumption on EAC risk are also inconclusive. In a case-control study from Italy, increasing fiber intake was associated with decreased odds of esophageal cancer (all cell types) (trend OR $0.70 ; 95 \%$ CI $0.51-0.96$ ) [Soler et al. 2001]. In a randomized controlled trial of 87 patients with $\mathrm{BE}$ followed for three years, following a low-fat, high-fiber diet was not associated with any change in tissue expression of $\mathrm{Ki}-67$ and presence of aneuploidy, two markers associated with neoplastic progression in BE [Kristal et al. 2005].

Carbonated soft drinks increase acid reflux symptoms such as heartburn [Fass et al. 2005]. In a population-based case-control study, increased consumption of carbonated soft drinks was surprisingly associated with a decreased odds of EAC (OR 0.47; 95\% CI 0.29-0.76) [Mayne et al. 2006]. This effect was largely due to the consumption of diet soft drinks, which in theory may be associated with other healthy habits. A separate population-based case-control study from Sweden found no association between high-carbonated soft drink consumption and odds of EAC (OR 0.89; 95\% CI 0.49-1.64) [Lagergren et al. 2006].

\section{Antioxidants}

Chronic inflammatory states such as reflux esophagitis can result in the generation of free radicals derived from oxygen and nitrogen [Federico et al. 2007]. These free radicals can promote carcinogenesis via numerous different means, including direct DNA damage and inhibition of DNA repair mechanisms, inhibition of apoptosis, and activation of cellular proliferation pathways. Antioxidants, such as carotenoids and vitamins $\mathrm{C}$ and $\mathrm{E}$, bind with reactive oxygen and nitrogen species to neutralize their damaging effects. In a population-based case-control study from Sweden, both high beta-carotene use (OR $0.5 ; 95 \%$ CI $0.3-0.9$ ) and high overall antioxidant use (OR 0.5 ; 95\% CI 0.3-0.9) were associated with a reduced odds of EAC [Terry et al. 2000].

The enzyme superoxide dismutase (SOD) plays an important role in protection against the effects of oxidative stress [Farhadi et al. 2002]. Tissue SOD levels are lower in BE than in normal squamous esophageal mucosa. In one study, patients with $\mathrm{BE}$ and dysplasia were found to have increased levels of tissue SOD compared to nondysplastic BE [Sihvo et al. 2002]. A separate study demonstrated decreased SOD expression with more advanced neoplasia in BE [Hermann et al. 2005]. Rats fed diets supplemented with manganese-SOD developed significantly fewer EACs as compared to control rats [Martin et al. 2007; Piazuelo et al. 2005].

Nitric oxide and other reactive nitrogen species are also hypothesized to play a role in the carcinogenic effects of both acid and bile reflux [Clemons et al. 2007; Iijima et al. 2003]. Thiazolidine-4-carboxylic acid, or thioproline, has been shown to be an effective nitrite-trapping agent [Tsuda and Kurashima, 1991]. In animal models of gastroduodenal reflux, two separate studies reported that significantly fewer rats who received diets enriched with thioproline developed EAC as compared to control rats [Sasaki et al. 2007; Kumagai et al. 2004]. There are no published studies to date of the use of thioproline for the prevention of neoplastic progression in $\mathrm{BE}$.

Given the experience of the Beta Carotene and Retinol Efficacy Trial, in which subjects who received beta-carotene and vitamin $\mathrm{A}$ had an increased risk of lung cancer [Omenn et al. 1996], a randomized controlled trial 
demonstrating efficacy is mandatory before antioxidant use can be advocated for the prevention of EAC.

\section{Vitamin A}

Retinoic acid is excreted in bile, undergoes enterohepatic recirculation, and may therefore be present in significant amounts in gastroduodenal refluxate in the esophagus. Abnormal or decreased retinoic acid activity is thought to play a role in the development of various malignancies [Sun and Lotan, 2002]. A populationbased case-control study from the United States reported a reduced odds of EAC in the highest quartile of dietary intake of vitamin A (OR 0.5, $p=0.05$ ) [Chen et al. 2002]. A recent crosssectional in vitro study demonstrated decreased tissue levels of retinoic acid in BE-associated dysplasia (compared to nondysplastic BE) as well as increasing expression of CYP26A1, a key enzyme involved in retinoic acid metabolism [Chang et al. 2007a]. However, there is also evidence suggesting that esophageal exposure to retinoic acid may promote the development of intestinal metaplasia [Chang et al. 2007b] and may play a role in neoplastic progression to EAC [Hormi-Carver et al. 2007; Lord et al. 2001]. Given the conflicting laboratory data and the results of the Beta Carotene and Retinol Efficacy Trial [Omenn et al. 1996], vitamin A cannot, at present, be recommended for the prevention of EAC.

\section{Medications}

Male sex is an independent risk factor for EAC and may be a significant risk factor for progression in patients with $\mathrm{BE}$, possibly due to the protective effects of exposure to estrogen and progesterone. However, several populationbased case-control and cohort studies have failed to demonstrate a significant association between hormone replacement therapy or other forms of estrogen exposure and risk of EAC [Chandanos et al. 2006; Lindblad et al. 2006; Lagergren and Jansson, 2005; Lagergren and Nyren, 1998].

Angiotensin converting enzyme inhibitors (ACEIs) have anti-inflammatory properties in addition to their blood pressure lowering effects [Ferrario and Strawn, 2006]. A single population-based case control study in the UK showed no significant association between
ACEI use and risk of EAC (OR $0.71 ; 95 \%$ CI 0.43-1.17) [Sjoberg et al. 2007].

\section{Cost effectiveness of chemoprevention}

The utility of chemoprevention of EAC depends on several factors, including efficacy, cost, and safety. At present, endoscopic surveillance of patients with $\mathrm{BE}$ is relied upon as the sole means of attempting to improve outcomes in and decrease the disease burden of EAC.

Sonnenberg and Fennerty [2003] performed a cost-effectiveness study of chemoprevention with NSAIDs for EAC. The primary Markov model from these analyses assumed a progression rate of $0.5 \%$ per year from $\mathrm{BE}$ to EAC and a $50 \%$ efficacy for NSAIDs in preventing EAC. The authors concluded that NSAIDs in addition to endoscopic surveillance in BE patients was cost effective, with an incremental cost-effectiveness ratio $<\$ 30,000$ per life-year saved. One of the limitations of the model was the lack of incorporation of low- and high-grade dysplasia as disease states and their associated shorter endoscopic surveillance intervals.

Hur et al. [2004] performed a cost-effectiveness study of chemoprevention with aspirin for patients with $\mathrm{BE}$. The model included the health states of BE with no dysplasia, lowgrade, and high-grade dysplasia, with varying surveillance intervals for each one. They found that a combination of aspirin therapy and endoscopic surveillance resulted in both decreased cost as well as increased quality-adjusted life years (QALYs). One of the principal assumptions of the models was that aspirin would also decrease the risk of EAC by $50 \%$. In the sensitivity analyses, the combination strategy was only superior to endoscopic surveillance alone if aspirin reduced the risk of EAC by at least $40 \%$.

Given the relatively low incidence of EAC in patients with BE, any chemopreventive agent needs to be both extremely effective at preventing EAC as well as extremely safe in order to be a cost-effective addition to endoscopic surveillance.

\section{Conclusions}

To date, NSAIDs and PPIs are the best-studied potential agents for the prevention of EAC. For several years, PPIs have been prescribed to the large majority of patients who carry a diagnosis 
of BE, yet the overall incidence of EAC continues to rise. The protective effects of NSAIDs are consistent in the published epidemiologic studies. It is hoped that the randomized controlled AsPECT trial will provide important answers with regard to the utility of NSAIDs and PPIs for the prevention of EAC. Other agents, such as folic acid, green tea, and black raspberries, are promising candidates but have yet to be rigorously studied in humans. Hopefully, the results of future randomized controlled trials combined with improved risk stratification will result in chemopreventive strategies that will successfully reduce the incidence of and improve overall outcomes in EAC.

\section{Conflict of interest statement}

None declared

\section{References}

Abdalla, S.I., Lao-Sirieix, P., Novelli, M.R., Lovat, L.B., Sanderson, I.R. and Fitzgerald, R.C. (2004) Gastrin-induced cyclooxygenase-2 expression in Barrett's carcinogenesis. Clin Cancer Res 10: 4784-4792.

Abdalla, S.I., Sanderson, I.R. and Fitzgerald, R.C. (2005) Effect of inflammation on cyclooxygenase (COX)-2 expression in benign and malignant oesophageal cells. Carcinogenesis 26: 1627-1633.

Anderson, L.A., Johnston, B.T., Watson, R.G., Murphy, S.J., Ferguson, H.R., Comber, H. et al. (2006) Nonsteroidal anti-inflammatory drugs and the esophageal inflammation-metaplasia-adenocarcinoma sequence. Cancer Res 66: 4975-4982.

Arber, N., Eagle, C.J., Spicak, J., Racz, I., Dite, P., Hajer, J. et al. (2006) Celecoxib for the prevention of colorectal adenomatous polyps. $N$ Engl f Med 355: 885-895.

Bardou, M., Barkun, A.N., Ghosn, J., Hudson, M. and Rahme, E. (2004) Effect of chronic intake of NSAIDs and cyclooxygenase 2-selective inhibitors on esophageal cancer incidence. Clin Gastroenterol Hepatol 2: $880-887$.

Baron, J.A., Cole, B.F., Sandler, R.S., Haile, R.W., Ahnen, D., Bresalier, R. et al. (2003) A randomized trial of aspirin to prevent colorectal adenomas. $N \mathrm{Engl}$ 7 Med 348: 891-899.

Baron, J.A., Sandler, R.S., Haile, R.W., Mandel, J.S., Mott, L.A. and Greenberg, E.R. (1998) Folate intake, alcohol consumption, cigarette smoking, and risk of colorectal adenomas. $\mathcal{F}$ Natl Cancer Inst 90: 57-62.

Bertagnolli, M.M., Eagle, C.J., Zauber, A.G., Redston, M., Solomon, S.D., Kim, K. et al. (2006) Celecoxib for the prevention of sporadic colorectal adenomas. $N$ Engl f Med 355: 873-884.
Buttar, N.S., Wang, K.K., Anderson, M.A., Dierkhising, R.A., Pacifico, R.J., Krishnadath, K.K. et al. (2002a) The effect of selective cyclooxygenase-2 inhibition in Barrett's esophagus epithelium: an in vitro study. F Natl Cancer Inst 94: 422-429.

Buttar, N.S., Wang, K.K., Leontovich, O., Westcott, J.Y., Pacifico, R.J., Anderson, M.A. et al. (2002b) Chemoprevention of esophageal adenocarcinoma by COX-2 inhibitors in an animal model of Barrett's esophagus. Gastroenterology 122: 1101-1112.

Cabrera, C., Artacho, R. and Gimenez, R. (2006) Beneficial effects of green tea-a review. 7 Am Coll Nutr 25: 79-99.

Chandanos, E., Lindblad, M., Jia, C., Rubio, C.A., Ye, W. and Lagergren, J. (2006) Tamoxifen exposure and risk of oesophageal and gastric adenocarcinoma: a population-based cohort study of breast cancer patients in Sweden. Br F Cancer 95: 118-122.

Chang, C.L., Hong, E., Lao-Sirieix, P. and Fitzgerald, R.C. (2007a) A novel role for the retinoic acidcatabolizing enzyme CYP26A1 in Barrett's associated adenocarcinoma. Oncogene (2008) 27: 2951-60.

Chang, C.L., Lao-Sirieix, P., Save, V., De La Cueva

Mendez, G., Laskey, R. and Fitzgerald, R.C. (2007b) Retinoic acid-induced glandular differentiation of the oesophagus. Gut 56: 906-917.

Chen, H., Tucker, K.L., Graubard, B.I.,

Heineman, E.F., Markin, R.S., Potischman, N.A. et al. (2002) Nutrient intakes and adenocarcinoma of the esophagus and distal stomach. Nutr Cancer 42: 33-40.

Chen, T., Hwang, H., Rose, M.E., Nines, R.G. and Stoner, G.D. (2006) Chemopreventive properties of black raspberries in N-nitrosomethylbenzylamineinduced rat esophageal tumorigenesis: downregulation of cyclooxygenase- 2 , inducible nitric oxide synthase, and c-Jun. Cancer Res 66: 2853-2859.

Cheng, K.K., Sharp, L., McKinney, P.A., Logan, R.F., Chilvers, C.E., Cook-Mozaffari, P. et al. (2000) A case-control study of oesophageal adenocarcinoma in women: a preventable disease. $\mathrm{Br} \mathcal{F}$ Cancer 83: 127-132.

Choi, S.W. and Mason J.B. (2000) Folate and carcinogenesis: an integrated scheme. F Nutr 130: 129-132.

Chow, W.H., Finkle, W.D., McLaughlin, J.K., Frankl, H., Ziel, H.K. and Fraumeni Jr, J.F. (1995) The relation of gastroesophageal reflux disease and its treatment to adenocarcinomas of the esophagus and gastric cardia. Fama 274: 474-477.

Clemons, N.J., McColl, K.E. and Fitzgerald, R.C. (2007) Nitric oxide and acid induce double-strand DNA breaks in Barrett's esophagus carcinogenesis via distinct mechanisms. Gastroenterology 133: 1198-1209.

Cole, B.F., Baron, J.A., Sandler, R.S., Haile, R.W., Ahnen, D.J., Bresalier, R.S. et al. (2007) Folic acid for 
the prevention of colorectal adenomas: a randomized clinical trial. Fama 297: 2351-2359.

Cooper, B.T., Chapman, W., Neumann, C.S. and Gearty, J.C. (2006) Continuous treatment of Barrett's oesophagus patients with proton pump inhibitors up to 13 years: observations on regression and cancer incidence. Aliment Pharmacol Ther 23: 727-733.

Corley, D.A., Kerlikowske, K., Verma, R. and Buffler, P. (2003) Protective association of aspirin/ NSAIDs and esophageal cancer: a systematic review and meta-analysis. Gastroenterology 124: 47-56.

Corley, D.A., Levin, T.R., Habel, L.A., Weiss, N.S. and Buffler, P.A. (2002) Surveillance and survival in Barrett's adenocarcinomas: a population-based study. Gastroenterology 122: 633-640.

D’Alessandro, T., Prasain, J., Benton, M.R., Botting, N., Moore, R., Darley-Usmar, V. et al. (2003) Polyphenols, inflammatory response, and cancer prevention: chlorination of isoflavones by human neutrophils. F Nutr 133.

Duan, L., Wu, A.H., Sullivan-Halley, J. and Bernstein, L. (2008) Nonsteroidal anti-inflammatory drugs and risk of esophageal and gastric adenocarcinomas in Los Angeles County. Cancer Epidemiol Biomarkers Prev 17: 126-134.

El-Serag, H.B., Aguirre, T.V., Davis, S., Kuebeler, M., Bhattacharyya, A. and Sampliner, R.E. (2004a) Proton pump inhibitors are associated with reduced incidence of dysplasia in Barrett's esophagus. Am $\mathcal{F}$ Gastroenterol 99: 1877-1883.

El-Serag, H.B., Petersen, N.J., Carter, J., Graham, D.Y., Richardson, P., Genta, R.M. et al. (2004b) Gastroesophageal reflux among different racial groups in the United States. Gastroenterology 126: 1692-1699.

Farhadi, A., Fields, J., Banan, A. and Keshavarzian, A. (2002) Reactive oxygen species: are they involved in the pathogenesis of GERD, Barrett's esophagus, and the latter's progression toward esophageal cancer? Am $\mathcal{F}$ Gastroenterol 97: 22-26.

Farrow, D.C., Vaughan, T.L., Hansten, P.D., Stanford, J.L., Risch, H.A., Gammon, M.D. et al. (1998) Use of aspirin and other nonsteroidal antiinflammatory drugs and risk of esophageal and gastric cancer. Cancer Epidemiol Biomarkers Prev 7: 97-102.

Farrow, D.C., Vaughan, T.L., Sweeney, C., Gammon, M.D., Chow, W.H., Risch, H.A. et al. (2000) Gastroesophageal reflux disease, use of H2 receptor antagonists, and risk of esophageal and gastric cancer. Cancer Causes Control 11: 231-238.

Fass, R., Quan, S.F., O'Connor, G.T., Ervin, A. and Iber, C. (2005) Predictors of heartburn during sleep in a large prospective cohort study. Chest 127 : 1658-1666.

Feagins, L.A., Zhang, H.Y., Hormi-Carver, K., Quinones, M.H., Thomas, D., Zhang, X. et al. (2007) Acid has antiproliferative effects in nonneoplastic
Barrett's epithelial cells. Am $\mathcal{F}$ Gastroenterol 102: $10-20$.

Federico, A., Morgillo, F., Tuccillo, C., Ciardiello, F. and Loguercio, C. (2007) Chronic inflammation and oxidative stress in human carcinogenesis. Int $\mathcal{F}$ Cancer 121: 2381-2386.

Ferrario, C.M. and Strawn, W.B. (2006) Role of the renin-angiotensin-aldosterone system and proinflammatory mediators in cardiovascular disease. Am f Cardiol 98: 121-128.

Fiorucci, S., Santucci, L., Farroni, F., Pelli, M.A. and Morelli, A. (1989) Effect of omeprazole on gastroesophageal reflux in Barrett's esophagus. $A m \mathcal{F}$

Gastroenterol 84: 1263-1267.

Fitzgerald, R.C., Omary, M.B. and Triadafilopoulos, G. (1996) Dynamic effects of acid on Barrett's esophagus. An ex vivo proliferation and differentiation model. f Clin Invest 98: 2120-2128.

Freedman, N.D., Park, Y., Subar, A.F., Hollenbeck, A.R., Leitzmann, M.F., Schatzkin, A. et al. (2007) Fruit and vegetable intake and esophageal cancer in a large prospective cohort study. Int $\mathcal{F}$ Cancer 121: 2753-2760.

Funkhouser, E.M. and Sharp, G.B. (1995) Aspirin and reduced risk of esophageal carcinoma. Cancer 76 : 1116-1119.

Gammon, M.D., Terry, M.B., Arber, N., Chow, W.H., Risch, H.A., Vaughan, T.L. et al. (2004) Nonsteroidal anti-inflammatory drug use associated with reduced incidence of adenocarcinomas of the esophagus and gastric cardia that overexpress cyclin D1: a population-based study. Cancer Epidemiol Biomarkers Prev 13: 34-39.

Garcia Rodriguez, L.A., Lagergren, J. and Lindblad, M. (2006) Gastric acid suppression and risk of oesophageal and gastric adenocarcinoma: a nested case control study in the UK. Gut 55: 1538-1544.

Georgopoulos, S.D., Polymeros, D., Triantafyllou, K. Spiliadi, C., Mentis, A., Karamanolis, D.G. et al. (2006) Hypergastrinemia is associated with increased risk of distal colon adenomas. Digestion 74: 42-46.

Gillen, P., Keeling, P., Byrne, P.J. and Hennessy, T.P. (1987) Barrett's oesophagus: $\mathrm{pH}$ profile. Br f Surg 74: 774-776.

Giovannucci, E., Rimm, E.B., Ascherio, A., Stampfer, M.J., Colditz, G.A. and Willett, W.C. (1995) Alcohol, low-methionine-low-folate diets, and risk of colon cancer in men. $\mathcal{F}$ Natl Cancer Inst 87: 265-273.

Giovannucci, E., Stampfer, M.J., Colditz, G.A., Hunter, D.J., Fuchs, C., Rosner, B.A. et al. (1998) Multivitamin use, folate, and colon cancer in women in the Nurses' Health Study. Ann Intern Med 129: 517-524.

Gonzalez, C.A., Pera, G., Agudo, A., Bueno-deMesquita, H.B., Ceroti, M., Boeing, H. et al. (2006) Fruit and vegetable intake and the risk of stomach and 
oesophagus adenocarcinoma in the European Prospective Investigation into Cancer and Nutrition (EPIC-EURGAST). Int f Cancer 118: 2559-2566.

Haigh, C.R., Attwood, S.E., Thompson, D.G., Jankowski, J.A., Kirton, C.M., Pritchard, D.M. et al. (2003) Gastrin induces proliferation in Barrett's metaplasia through activation of the CCK2 receptor. Gastroenterology 124: 615-625.

Hao, Y., Sood, S., Triadafilopoulos, G., Kim, J.H., Wang, Z., Sahbaie, P. et al. (2007) Gene expression changes associated with Barrett's esophagus and Barrett's-associated adenocarcinoma cell lines after acid or bile salt exposure. BMC Gastroenterol 7(24): 1-10.

Harris, J.C., Clarke, P.A., Awan, A., Jankowski, J. and Watson, S.A. (2004) An antiapoptotic role for gastrin and the gastrin/CCK-2 receptor in Barrett's esophagus. Cancer Res 64: 1915-1919.

Heath, E.I., Canto, M.I., Piantadosi, S., Montgomery, E., Weinstein, W.M., Herman, J.G. et al. (2007) Secondary chemoprevention of Barrett's esophagus with celecoxib: results of a randomized trial. f Natl Cancer Inst 99: 545-557.

Hermann, B., Li, Y., Ray, M.B., Wo, J.M. and Martin, R.C.II. (2005) Association of manganese superoxide dismutase expression with progression of carcinogenesis in Barrett esophagus. Arch Surg 140: 1204-1209.

Hillman, L.C., Chiragakis, L., Shadbolt, B., Kaye, G.L. and Clarke, A.C. (2004) Proton-pump inhibitor therapy and the development of dysplasia in patients with Barrett's oesophagus. Med F Aust 180: 387-391.

Hillman, L.C., Chiragakis, L., Shadbolt, B., Kaye, G.L. and Clarke, A.C. (2008) Effect of proton pump inhibitors on markers of risk for highgrade dysplasia and oesophageal cancer in Barrett's oesophagus. Aliment Pharmacol Ther 27: 321-326.

Hormi-Carver, K., Feagins, L.A., Spechler, S.J. and Souza, R.F. (2007) All trans-retinoic acid induces apoptosis via p38 and caspase pathways in metaplastic Barrett's cells. Am f Physiol Gastrointest Liver Physiol 292: G18-27.

Howe, L.R. and Dannenberg, A.J. (2002) A role for cyclooxygenase-2 inhibitors in the prevention and treatment of cancer. Semin Oncol 29: 111-119.

Hur, C., Nishioka, N.S. and Gazelle, G.S. (2004) Cost-effectiveness of aspirin chemoprevention for Barrett's esophagus. F Natl Cancer Inst 96: 316-325.

Iijima, K., Grant, J., McElroy, K., Fyfe, V., Preston, T. and McColl, K.E. (2003) Novel mechanism of nitrosative stress from dietary nitrate with relevance to gastro-oesophageal junction cancers. Carcinogenesis 24: 1951-1960.

Jankowski, J. and Moayyedi, P. (2004) Re: Costeffectiveness of aspirin chemoprevention for Barrett's esophagus. F Natl Cancer Inst 96: 885-887.
Jemal, A., Siegel, R., Ward, E., Murray, T., Xu, J. and Thun, M.J. (2007) Cancer statistics, 2007. CA Cancer f Clin 57: 43-66.

Katz, P.O., Koch, F.K., Ballard, E.D., Bagin, R.G., Gautille, T.C., Checani, G.C. et al. (2007) Comparison of the effects of immediate-release omeprazole oral suspension, delayed-release lansoprazole capsules and delayed-release esomeprazole capsules on nocturnal gastric acidity after bedtime dosing in patients with night-time GERD symptoms. Aliment Pharmacol Ther 25: 197-205.

Katz, P.O., Scheiman, J.M. and Barkun, A.N. (2006) Review article: acid-related disease-what are the unmet clinical needs? Aliment Pharmacol Ther 23 Suppl 2: 9-22.

Kaur, B.S., Khamnehei, N., Iravani, M., Namburu, S.S., Lin, O. and Triadafilopoulos, G. (2002) Rofecoxib inhibits cyclooxygenase 2 expression and activity and reduces cell proliferation in Barrett's esophagus. Gastroenterology 123: $60-67$.

Koop, H., Klein, M. and Arnold, R. (1990) Serum gastrin levels during long-term omeprazole treatment. Aliment Pharmacol Ther 4: 131-138.

Kresty, L.A., Frankel, W.L., Hammond, C.D., Baird, M.E., Mele, J.M., Stoner, G.D. et al. (2006) Transitioning from preclinical to clinical chemopreventive assessments of lyophilized black raspberries: interim results show berries modulate markers of oxidative stress in Barrett's esophagus patients. Nutr Cancer 54: 148-156.

Kristal, A.R., Blount, P.L., Schenk, J.M., Sanchez, C.A., Rabinovitch, P.S., Odze, R.D. et al. (2005) Low-fat, high fruit and vegetable diets and weight loss do not affect biomarkers of cellular proliferation in Barrett esophagus. Cancer Epidemiol Biomarkers Prev 14: 2377-2383.

Kubo, A. and Corley, D.A. (2002) Marked regional variation in adenocarcinomas of the esophagus and the gastric cardia in the United States. Cancer 95: 2096-2102.

Kumagai, H., Mukaisho, K., Sugihara, H., Miwa, K., Yamamoto, G. and Hattori, T. (2004) Thioproline inhibits development of esophageal adenocarcinoma induced by gastroduodenal reflux in rats. Carcinogenesis 25: $723-727$.

Kusyk, C.J., McNiel, N.O. and Johnson, L.R. (1986) Stimulation of growth of a colon cancer cell line by gastrin. Am $\mathcal{F}$ Physiol 251: G597-601.

Lagergren, J., Bergstrom, R., Lindgren, A. and Nyren, O. (1999a) Symptomatic gastroesophageal reflux as a risk factor for esophageal adenocarcinoma. $N$ Engl f Med 340: 825-831.

Lagergren, J., Bergstrom, R. and Nyren, O. (1999b) Association between body mass and adenocarcinoma of the esophagus and gastric cardia. Ann Intern Med 130: 883-890. 
Lagergren, J. and Jansson, C. (2005) Sex hormones and oesophageal adenocarcinoma: influence of childbearing? Br f Cancer 93: 859-861.

Lagergren, J. and Nyren, O. (1998) Do sex hormones play a role in the etiology of esophageal adenocarcinoma? A new hypothesis tested in a population-based cohort of prostate cancer patients. Cancer Epidemiol Biomarkers Prev 7: 913-915.

Lagergren, J., Viklund, P. and Jansson, C. (2006) Carbonated soft drinks and risk of esophageal adenocarcinoma: a population-based case-control study. F Natl Cancer Inst 98: 1158-1161.

Lao-Sirieix, P., Roy, A., Worrall, C., Vowler, S.L., Gardiner, S. and Fitzgerald, R.C. (2006) Effect of acid suppression on molecular predictors for esophageal cancer. Cancer Epidemiol Biomarkers Prev 15: 288-293.

Larsson, S.C., Giovannucci, E. and Wolk, A. (2005) A prospective study of dietary folate intake and risk of colorectal cancer: modification by caffeine intake and cigarette smoking. Cancer Epidemiol Biomarkers Prev 14: 740-743.

Larsson, S.C., Giovannucci, E. and Wolk, A. (2006) Folate intake, MTHFR polymorphisms, and risk of esophageal, gastric, and pancreatic cancer: a meta-analysis. Gastroenterology 131: 1271-1283.

Lindblad, M., Garcia Rodriguez, L.A., Chandanos, E. and Lagergren, J. (2006) Hormone replacement therapy and risks of oesophageal and gastric adenocarcinomas. Br $\mathcal{F}$ Cancer 94: 136-141.

Lord, R.V., Tsai, P.I., Danenberg, K.D., Peters, J.H., Demeester, T.R., Tsao-Wei, D.D. et al. (2001) Retinoic acid receptor-alpha messenger RNA expression is increased and retinoic acid receptorgamma expression is decreased in Barrett's intestinal metaplasia, dysplasia, adenocarcinoma sequence. Surgery 129: 267-276.

Martin, R.C., Liu, Q., Wo, J.M., Ray, M.B. and Li, Y. (2007) Chemoprevention of carcinogenic progression to esophageal adenocarcinoma by the manganese superoxide dismutase supplementation. Clin Cancer Res 13: 5176-5182.

Masuda, M., Suzui, M., Lim, J.T. and Weinstein, I.B. (2003) Epigallocatechin-3-gallate inhibits activation of HER-2/neu and downstream signaling pathways in human head and neck and breast carcinoma cells. Clin Cancer Res 9: 3486-3491.

Masuda, M., Suzui, M. and Weinstein, I.B. (2001) Effects of epigallocatechin-3-gallate on growth, epidermal growth factor receptor signaling pathways, gene expression, and chemosensitivity in human head and neck squamous cell carcinoma cell lines. Clin Cancer Res 7: 4220-4229.

Mayne, S.T., Risch, H.A., Dubrow, R., Chow, W.H., Gammon, M.D., Vaughan, T.L. et al. (2006) Carbonated soft drink consumption and risk of esophageal adenocarcinoma. F Natl Cancer Inst 98: 72-75.
Mayne, S.T., Risch, H.A., Dubrow, R., Chow, W.H., Gammon, M.D., Vaughan, T.L. et al. (2001) Nutrient intake and risk of subtypes of esophageal and gastric cancer. Cancer Epidemiol Biomarkers Prev 10: 1055-1062.

Mehta, S., Boddy, A., Johnson, I.T. and Rhodes, M. (2006) Systematic review: Cyclo-oxygenase-2 in human oesophageal adenocarcinogenesis. Aliment Pharmacol Ther 24: 1321-1331.

Morgan, C., Alazawi, W., Sirieix, P., Freeman, T., Coleman, N. and Fitzgerald, R. (2004) In vitro acid exposure has a differential effect on apoptotic and proliferative pathways in a Barrett's adenocarcinoma cell line. Am f Gastroenterol 99: 218-224.

Morris, C.D., Armstrong, G.R., Bigley, G., Green, H. and Attwood, S.E. (2001) Cyclooxygenase-2 expression in the Barrett's metaplasia-dysplasiaadenocarcinoma sequence. Am $\mathcal{F}$ Gastroenterol 96: 990-996.

Omenn, G.S., Goodman, G.E., Thornquist, M.D., Balmes, J., Cullen, M.R., Glass, A. et al. (1996) Effects of a combination of beta carotene and vitamin A on lung cancer and cardiovascular disease. $N$ Engl f Med 334: 1150-1155.

Ouatu-Lascar, R., Fitzgerald, R.C. and Triadafilopoulos, G. (1999) Differentiation and proliferation in Barrett's esophagus and the effects of acid suppression. Gastroenterology 117: 327-335.

Piazuelo, E., Cebrian, C., Escartin, A., Jimenez, P., Soteras, F., Ortego, J. et al. (2005) Superoxide dismutase prevents development of adenocarcinoma in a rat model of Barrett's esophagus. World $\mathcal{F}$ Gastroenterol 11: 7436-7443.

Rex, D.K., Cummings, O.W., Shaw, M., Cumings, M.D., Wong, R.K., Vasudeva, R.S. et al. (2003) Screening for Barrett's esophagus in colonoscopy patients with and without heartburn.

Gastroenterology 125: 1670-1677.

Ronkainen, J., Aro, P., Storskrubb, T., Johansson, S.E., Lind, T., Bolling-Sternevald, E. et al. (2005) Prevalence of Barrett's esophagus in the general population: an endoscopic study. Gastroenterology 129: 1825-1831.

Saffari, Y. and Sadrzadeh, S.M. (2004) Green tea metabolite EGCG protects membranes against oxidative damage in vitro. Life Sci 74: 1513-1518.

Sandler, R.S., Halabi, S., Baron, J.A., Budinger, S., Paskett, E., Keresztes, R. et al. (2003) A randomized trial of aspirin to prevent colorectal adenomas in patients with previous colorectal cancer. $N$ Engl $\mathcal{F}$ Med 348: 883-890.

Sasaki, S., Miwa, K., Fujimura, T., Oba, M., Miyashita, T. and Kinami, S. (2007) Ingestion of thioproline suppresses rat esophageal adenocarcinogenesis caused by duodenogastroesophageal reflux. Oncol Rep 18: 1443-1449. 
Schlansky, B., Dimarino Jr, A.J., Loren, D., Infantolino, A., Kowalski, T. and Cohen, S. (2006) A survey of oesophageal cancer: pathology, stage and clinical presentation. Aliment Pharmacol Ther 23: 587-593.

Shaheen, N. and Ransohoff, D.F. (2002) Gastroesophageal reflux, barrett esophagus, and esophageal cancer: scientific review. Fama 287 : 1972-1981.

Shirvani, V.N., Ouatu-Lascar, R., Kaur, B.S., Omary, M.B. and Triadafilopoulos, G. (2000) Cyclooxygenase 2 expression in Barrett's esophagus and adenocarcinoma: Ex vivo induction by bile salts and acid exposure. Gastroenterology 118: 487-496.

Sihvo, E.I., Salminen, J.T., Rantanen, T.K., Ramo, O.J., Ahotupa, M., Farkkila, M. et al. (2002) Oxidative stress has a role in malignant transformation in Barrett's oesophagus. Int F Cancer 102: 551-555.

Sjoberg, T., Garcia Rodriguez, L.A. and Lindblad, M. (2007) Angiotensin-converting enzyme inhibitors and risk of esophageal and gastric cancer: a nested case-control study. Clin Gastroenterol Hepatol 5: 1160-1166e1.

Smith, J.P. and Solomon, T.E. (1988) Effects of gastrin, proglumide, and somatostatin on growth of human colon cancer. Gastroenterology 95: 1541-1548.

Sobhani, I., Lehy, T., Laurent-Puig, P., Cadiot, G., Ruszniewski, P. and Mignon, M. (1993) Chronic endogenous hypergastrinemia in humans: evidence for a mitogenic effect on the colonic mucosa. Gastroenterology 105: 22-30.

Soler, M., Bosetti, C., Franceschi, S., Negri, E., Zambon, P., Talamini, R. et al. (2001) Fiber intake and the risk of oral, pharyngeal and esophageal cancer. Int F Cancer 91: 283-287.

Sonnenberg, A. and Fennerty, M.B. (2003)

Medical decision analysis of chemoprevention against esophageal adenocarcinoma. Gastroenterology 124: 1758-1766.

Souza, R.F., Shewmake, K., Beer, D.G., Cryer, B. and Spechler, S.J. (2000) Selective inhibition of cyclooxygenase-2 suppresses growth and induces apoptosis in human esophageal adenocarcinoma cells. Cancer Res 60: 5767-5772.

Souza, R.F., Shewmake, K., Pearson, S., Sarosi Jr, G.A., Feagins, L.A., Ramirez, R.D. et al. (2004) Acid increases proliferation via ERK and p38 MAPKmediated increases in cyclooxygenase-2 in Barrett's adenocarcinoma cells. Am F Physiol Gastrointest Liver Physiol 287: G743-G748.

Souza, R.F., Shewmake, K., Terada, L.S. and Spechler, S.J. (2002) Acid exposure activates the mitogen-activated protein kinase pathways in Barrett's esophagus. Gastroenterology 122: 299-307.

Spechler, S.J. (2002) Clinical practice. Barrett's Esophagus. N Engl F Med 346: 836-842.
Stoner, G.D., Wang, L.S., Zikri, N., Chen, T., Hecht, S.S., Huang, C. et al. (2007) Cancer prevention with freeze-dried berries and berry components. Semin Cancer Biol 17: 403-410.

Sun, C.L., Yuan, J.M., Koh, W.P. and Yu, M.C. (2006) Green tea, black tea and colorectal cancer risk: a meta-analysis of epidemiologic studies. Carcinogenesis 27: 1301-1309.

Sun, S.Y. and Lotan, R. (2002) Retinoids and their receptors in cancer development and chemoprevention. Crit Rev Oncol Hematol 41: 41-55.

Terry, P., Lagergren, J., Hansen, H., Wolk, A. and Nyren, O. (2001) Fruit and vegetable consumption in the prevention of oesophageal and cardia cancers. Eur f Cancer Prev 10: 365-369.

Terry, P., Lagergren, J., Ye, W., Nyren, O. and Wolk, A. (2000) Antioxidants and cancers of the esophagus and gastric cardia. Int $\mathcal{F}$ Cancer 87: 750-754.

Thorburn, C.M., Friedman, G.D., Dickinson, C.J., Vogelman, J.H., Orentreich, N. and Parsonnet, J. (1998) Gastrin and colorectal cancer: a prospective study. Gastroenterology 115: 275-280.

Tsuda, M. and Kurashima, Y. (1991) Nitritetrapping capacity of thioproline in the human body. IARC Sci Publ 00: 123-128.

Umansky, M., Yasui, W., Hallak, A., Brill, S., Shapira, I., Halpern, Z. et al. (2001) Proton pump inhibitors reduce cell cycle abnormalities in Barrett's esophagus. Oncogene 20: 7987-7991.

Sandick, J.W., van Lanschot, J.J., Kuiken, B.W., Tytgat, G.N., Offerhaus, G.J. and Obertop, H. (1998) Impact of endoscopic biopsy surveillance of Barrett's oesophagus on pathological stage and clinical outcome of Barrett's carcinoma. Gut 43: 216-222.

Vaughan, T.L., Dong, L.M., Blount, P.L., Ayub, K., Odze, R.D., Sanchez, C.A. et al. (2005) Non-steroidal anti-inflammatory drugs and risk of neoplastic progression in Barrett's oesophagus: a prospective study. Lancet Oncol 6: 945-952.

Vizcaino, A.P., Moreno, V., Lambert, R. and Parkin, D.M. (2002) Time trends incidence of both major histologic types of esophageal carcinomas in selected countries, 1973-1995. Int f Cancer 99: $860-868$.

Wilson, K.T., Fu, S., Ramanujam, K.S. and Meltzer, S.J. (1998) Increased expression of inducible nitric oxide synthase and cyclooxygenase- 2 in Barrett's esophagus and associated adenocarcinomas. Cancer Res 58: 2929-2934.

Wright, T.A., Gray, M.R., Morris, A.I., Gilmore, I.T., Ellis, A., Smart, H.L. et al. (1996) Cost effectiveness of detecting Barrett's cancer. Gut 39: 574-579.

Yang, G., Shu, X.O., Li, H., Chow, W.H., Ji, B.T., Zhang, X. et al. (2007) Prospective cohort study 
of green tea consumption and colorectal cancer risk in women. Cancer Epidemiol Biomarkers Prev 16: 1219-1223.

Visit SAGE journals online http://tag.sagepub.com

(SAGEJOURNALS

Online
Zhang, F., Altorki, N.K., Wu, Y.C., Soslow, R.A., Subbaramaiah, K. and Dannenberg, A.J. (2001) Duodenal reflux induces cyclooxygenase-2 in the esophageal mucosa of rats: evidence for involvement of bile acids. Gastroenterology 121: 1391-1399.

Zhang, H.Y., Zhang, X., Hormi-Carver, K., Feagins, L.A., Spechler, S.J. and Souza, R.F. (2007) In non-neoplastic Barrett's epithelial cells, acid exerts early antiproliferative effects through activation of the Chk2 pathway. Cancer Res 67: 8580-8587. 